ANL-6070

Metallurgy and Ceramics

(TID-4500, 15th Ed.)

$A E C$ Research and

Development Report

\author{
ARGONNE NATIONAL LABORATORY \\ 9700 S. Cass Avenue \\ Argonne, Illinois
}

\title{
AQUEOUS CORROSION OF MAGNESIUM ALLOYS \\ by
}

S. Greenberg and W. E. Ruther

Metallurgy Division

May 1960

Portions of the material in this report

have appeared in the following

Metallurgy Division Quarterly Reports:

\begin{tabular}{ll} 
Number & \multicolumn{1}{c}{ Page $(\mathrm{s})$} \\
ANL-4580 & 23 \\
ANL-4576 & $83,86,87$ \\
ANL-5257 & 59,60 \\
ANL-5717 & 45,46 \\
ANL-5797 & 26 \\
ANL-5837 & $33-37$ \\
ANL-5975 & 29
\end{tabular}

Operated by The University of Chicago

under

Contract $W-31-109-$ eng-38 


\section{DISCLAIMER}

This report was prepared as an account of work sponsored by an agency of the United States Government. Neither the United States Government nor any agency Thereof, nor any of their employees, makes any warranty, express or implied, or assumes any legal liability or responsibility for the accuracy, completeness, or usefulness of any information, apparatus, product, or process disclosed, or represents that its use would not infringe privately owned rights. Reference herein to any specific commercial product, process, or service by trade name, trademark, manufacturer, or otherwise does not necessarily constitute or imply its endorsement, recommendation, or favoring by the United States Government or any agency thereof. The views and opinions of authors expressed herein do not necessarily state or reflect those of the United States Government or any agency thereof. 


\section{DISCLAIMER}

Portions of this document may be illegible in electronic image products. Images are produced from the best available original document. 


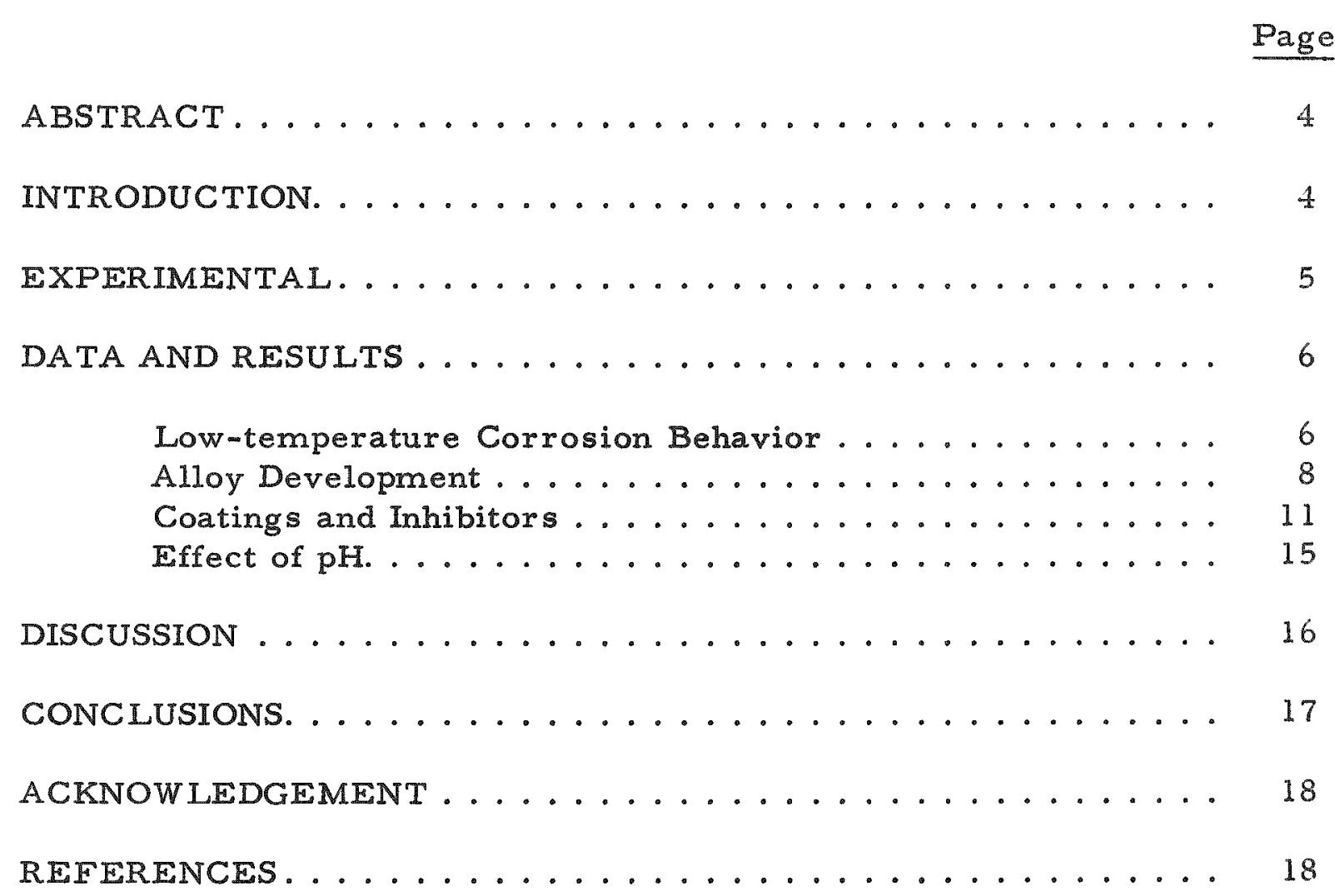




\section{LIST OF FIGURES}

No.

Title

$\underline{\text { Page }}$

1 Corrosion of Magnesium Alloys in Distilled Water at

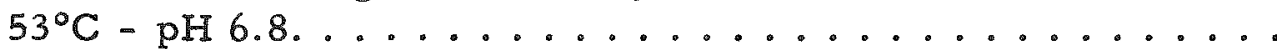

2 Corrosion of Magnesium Alloys in Dilute Potassium Hydroxide Solution at $90^{\circ} \mathrm{C} \ldots \ldots \ldots 7$

3 Corrosion of AZ-31 Magnesium in Fluoride Solutions.... 13

4 Appearance of AZ-31 Magnesium Alloy Corroded in $10 \mathrm{ppm}$ Fluoride $(\mathrm{NaF})$ Solution at $150^{\circ} \mathrm{C} \ldots \ldots \ldots$

\section{LIST OF TABLES}

No.

Title

Page

I Corrosion of Commercial Magnesium Alloys in Initially Pure Water at $150^{\circ} \mathrm{C} \ldots \ldots \ldots \ldots$

II Corrosion of Developmental Magnesium Alloys in Initially Pure Water at $150^{\circ} \mathrm{C} \ldots \ldots$

III Effect of Aluminum Content on Corrosion of Some Magnesium Alloys in Initially Pure Water at $150^{\circ} \mathrm{C} \ldots \ldots . .10$

IV Effect of Copper Content on Corrosion of Some Magnesium Alloys in Initially Pure Water at $150^{\circ} \mathrm{C} \ldots \ldots . . . . .10$

V Effect of Tin Content on Corrosion of Some Magnesium Alloys in Initially Pure Water at $150^{\circ} \mathrm{C} \ldots \ldots 10$

VI Experimental Coatings Applied to AZ-31 Magnesium .... 12

VII Effect of Fluoride Concentration on Corrosion of Magnesium Alloy $\mathrm{AZ}-31$ at $150^{\circ} \mathrm{C} \ldots \ldots \ldots$

VIII Corrosion of Magnesium and Magnesium Alloys in Aqueous Halide Solutions at $150^{\circ} \mathrm{C} \ldots \ldots \ldots \ldots 14$

IX Effect of $\mathrm{pH}$ on Aqueous Corrosion of Magnesium Alloys at $150^{\circ} \mathrm{C}$ 


\title{
AQUEOUS CORROSION OF MAGNESIUM ALLOYS
}

by

S. Greenberg and W. E. Ruther

\begin{abstract}
The aqueous corrosion of magnesium alloys was investigated over the range from 53 to $150^{\circ} \mathrm{C}$. Corrosion rates rose rapidly with temperature, reaching about 3 mils per day at $150^{\circ} \mathrm{C}$ for $\mathrm{AZ}-3 \mathrm{I}[\mathrm{Mg}-2.5$ to $3.5 \mathrm{w} / \mathrm{o} \mathrm{Al}-0.7$ to $1.3 \mathrm{w} / \mathrm{o}$ $\mathrm{Zn}-0.2 \mathrm{w} / \mathrm{OMn}$. Additions of small amounts of copper and/or nickel to the basic AZ-31 composition reduced the corrosion rate at $150^{\circ}$ by a factor of about two. Tin may be advantageously substituted for zinc in $\mathrm{AZ}-31$.

Control of the pH in the range between 6 and 7 and maintenance of a fluoride concentration in the range between 1 and 10 ppm reduced the corrosion rate of $A Z-31$ and of the Argonne experimental alloys to about 0.1 mil per day at $150^{\circ} \mathrm{C}$.
\end{abstract}

\section{INTRODUCTION}

The low thermal neutron capture cross section of magnesium makes it an attractive possibility for a cladding material for the fuel of a nuclear reactor. Relatively little data are available concerning the corrosion resistance of magnesium alloys in a pure water environment, such as might be found in a water-cooled reactor. Aqueous corrosion testing of these alloys reported in the literature $(1,2)$ has been largely confined to temperatures below $100^{\circ} \mathrm{C}$ and to the usual type of corrosion-evaluating solutions (i.e., $3 \% \mathrm{NaCl}$ )。

Two unpublished sets of experiments pertinent to this report were performed by members of the ANL Reactor Engineering Division concurrently with the Metallurgy programs. L. E. Link in two short dynamic tests $(25 \mathrm{ft} / \mathrm{sec})$ at $60^{\circ} \mathrm{C}$ found that $\mathrm{AZ}-31$ alloy incurred much higher weight changes when the ion exchanger was more effective in removing the corrosion products from the test solution.

N. R. Grant, using small unrefreshed test chambers, obtained average corrosion rates (during 5-day tests) fitting the curve

$$
\log _{1}[\text { Corrosion Rate }(\text { mils } / \text { day })]=0.0375 \mathrm{~T}\left({ }^{\circ} \mathrm{C}\right)-5.20
$$


over the range from 80 to $150^{\circ} \mathrm{C}$ for $\mathrm{AZ}-31$ alloy. There was not much change in rate between 30 and $80^{\circ} \mathrm{C}(0.004 \pm 0.002 \mathrm{mil} /$ day $)$.

Two specific ANL designs of water-cooled reactors have considered the use of magnesium cladding. The first of these designs (19501952) involved relatively low water temperature $\left(50-90^{\circ} \mathrm{C}\right)$ and a long, reliable service life. The experimental work described in this report for this temperature range was performed in connection with these requirements.

More recently, a research reactor producing a very high neutron flux level was conceived which would make use of magnesium cladding. Due to the extremely short fuel lifetime ( 5 days), a much higher corrosion rate could be tolerated (estimated maximum of 0.001 in. per day) at the design temperature of $150^{\circ} \mathrm{C}$. The major portion of this report is concerned with the preliminary exploration, alloy development and inhibitor selection necessary to meet this design corrosion rate.

\section{EXPERIMENTAL}

Commercial magnesium alloys were obtained from the Dow Chemical Co. Pure magnesium, used in the preparation of the experimental alloys, was obtained from Dominion Magnesium Ltd. (Doma1). The Brooks and Perkins Co. prepared several special magnesium alloy castings. Both Howard. Foundry and Dow cast commercial size ingots to ANL specifications. These were subsequently extruded into tubing by the Precision Extrusion Co. and by Magnode Products.

The developmental alloys for the high-temperature phase of the program were prepared by induction melting in an argon atmosphere and chill casting into a small, water-cooled copper mold. Sheet stock was fabricated from the castings by hot pressing and rolling.

Corrosion tests below $100^{\circ} \mathrm{C}$ were performed in either a refreshed Pyrex glass system under essentially stagnant conditions or in a 2-liter capacity Pyrex and stainless steel dynamic test loop previously described in detail. (3) The loop had means for maintaining gas saturation of the liquid and was modified in later tests to provide a constant replenishment of the test solution.

Preliminary corrosion tests of alloys and inhibitors at temperatures above $100^{\circ} \mathrm{C}$ were performed in small stainless steel autoclaves. The test conditions could not be accurately maintained because of contamination of the solution by corrosion products and the depletion of the inhibitors. More meaningful studies were run in stainless steel, constantly refreshed systems, (4) in which it was possible to control solution 
composition. In the latter systems the rate of replenishing solution was low enough so that the linear velocity past the samples was essentially zero.

Samples were annealed for one-half hour at $260^{\circ} \mathrm{C}$ and wet ground (240-grit) prior to exposure. In a few cases, samples prepared in this fashion were corrosion tested with other samples in the as-rolled condition. There was no appreciable difference in results.

The samples were electrically insulated from the stainless steel system with synthetic sapphire rods. The corrosion products were removed at the conclusion of the test by immersing the samples in boiling $15 \%$ chromic acid for one to three minutes.

The solution resulting from the high-temperature corrosion of magnesium-aluminum alloys contained a colloidal dispersion, probably magnesium or aluminum hydroxide. When a conventional glass electrode pH meter was used to determine the pH of such solutions at room temperature, difficulty was encountered at $\mathrm{pH}$ values below the 10-11 range. After an initial relatively low reading, the value rapidly increased to about 10.5. Values obtained with $\mathrm{pH}$ indicating paper corresponded to the initial value obtained with the $\mathrm{pH}$ meter. $\mathrm{pH}$ values are given as a range to express this uncertainty.

\section{DATA AND RESULTS}

\section{Low-Temperature Corrosion Behavior}

Initial testing of magnesium alloys was performed at $53^{\circ} \mathrm{C}$. The hydrogen-saturated distilled water was continuously refreshed so that

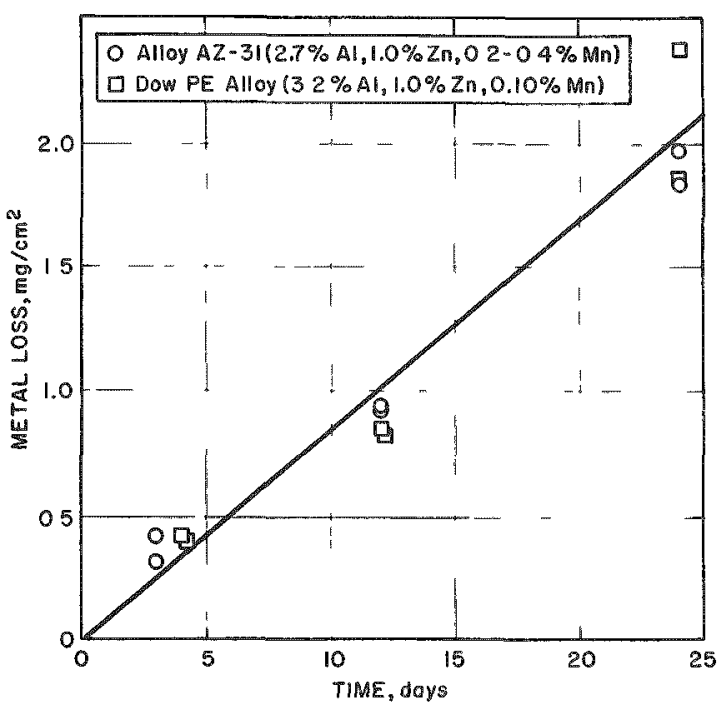

FIGURE I. CORROSION OF MAGNESIUM ALLOYS IN DISTILLED WATER AT $53^{\circ} \mathrm{C}-\mathrm{pH} 6.8$ the $\mathrm{pH}$ remained at 6.8 . The results are shown in Figure 1. The corrosion was roughly linear with time (24-day test) and a rate of $8.6 \mathrm{mdd}$ (milligrams/decimeter ${ }^{2} /$ day) was obtained.

Samples of $A Z-31 / a 1 l o y$ $(\mathrm{Mg}-2.7 \mathrm{w} / 0 \mathrm{Al}-1.0 \mathrm{w} / 0 \mathrm{Zn}-0.4 \mathrm{w} / \mathrm{o}$ $\mathrm{Mn})$ were tested in stagnant closed Pyrex chambers at the same temperature. Very little attack occurred (35-day test duration) if the water was deoxygenated at the start with tank nitrogen. Coupling with mild steel had no visible effect on the slight corrosion observed. When oxygen was present, much 
heavier corrosion occurred. The pH remained at $10.0 \pm 0.02$ in these tests, apparently controlled by the magnesium corrosion product.

Four experimental runs were made in the dynamic system at $90^{\circ} \mathrm{C}$. Dilute alkali solution was used. The potassium hydroxide solution was made up to $\mathrm{pH} 10.0$, since tests at lower temperatures had indicated this to be approximately the pH of the solution which magnesium will maintain by the corrosion process. In the first two tests, no special provision was made to maintain the pH. A small amount of solution was added as required to maintain the water level in the system. In these cases, the pH diminished rather rapidly for the first several days and then more slowly, reaching a value of the order of 8.2 at the end of the twenty-day test.

It was suspected that the drop in $\mathrm{pH}$ was due to air (containing $\mathrm{CO}_{2}$ ) leaking into the system. The tests were repeated for alloy $A Z-31$ with small continuous addition of fresh solution in an effort to maintain the original $\mathrm{pH}$. In these tests the solution $\mathrm{pH}$ dropped from 10.0 to 9.7. The flow rate was $17 \mathrm{ft} / \mathrm{sec}$ as compared with $20 \mathrm{ft} / \mathrm{sec}$ in the first two tests. One test was run with oxygen gas saturation and the other with helium gas saturation. Results of these tests are shown in Figure 2. Unlike the previously described stagnant test at $53^{\circ} \mathrm{C}$, there was no significant difference between the behavior of the samples in oxygen-saturated solution and that in helium-saturated solution. Corrosion rates subsequent to the first ten days were of the order of 15 mdd at pH slightly below 8.5 and a flow rate of $20 \mathrm{ft} / \mathrm{sec} ; 25 \mathrm{mdd}$ at $\mathrm{pH} 9.7$ and flow rate of $17 \mathrm{ft} / \mathrm{sec}$.

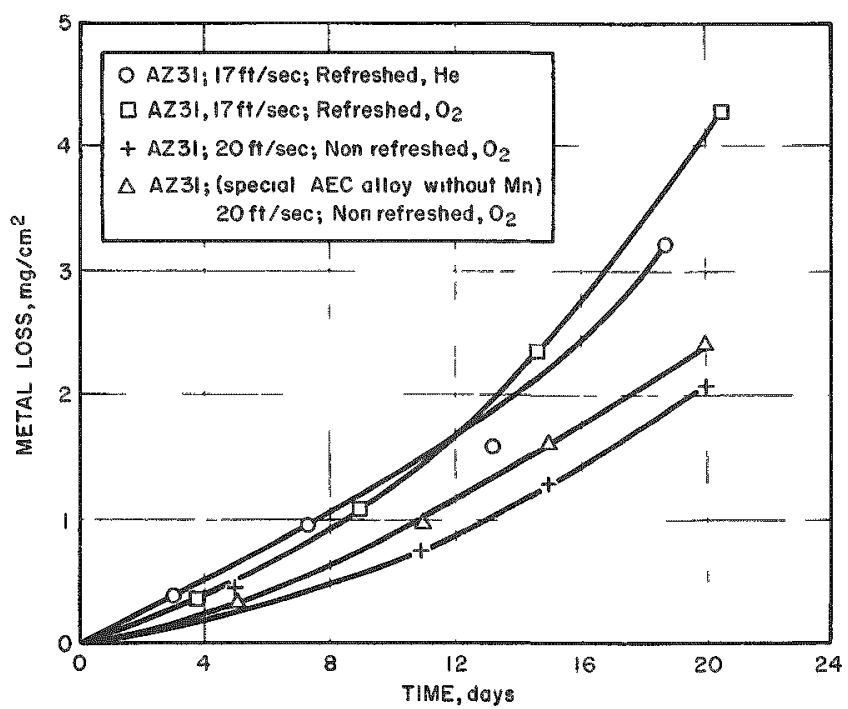

FIGURE 2. CORROSION OF MAGNESIUM ALLOYS IN DILUTE POTASSIUM HYDROXIDE SOLUTION AT $90^{\circ} \mathrm{C}$
Preliminary corrosion testing at higher temperatures (see Table I) clearly indicated that none of the common commercial alloys would meet the $1-\mathrm{mil} /$ day maximum rate specification previously mentioned. The high thorium content of alloy $\mathrm{HZ}-32$ precluded its use as a reactor cladding material.

As shown in Table $I$, the reaction at $150^{\circ} \mathrm{C}$ is much more rapid than at lower temperatures ( $1 \mathrm{mil} / \mathrm{day}=435 \mathrm{mdd}$ ). Samples which were not completely destroyed during the test were

covered with plates of nonadherent, white corrosion product. Exposures for varying lengths of time at the same temperature indicated that the corrosion rate was constant for at least a 7-day period. 
TABLE I

Corrosion of Commercial Magnesium Alloys in Initially Pure Water

\begin{tabular}{|c|c|c|c|c|c|c|c|c|c|c|c|c|}
\hline \multirow{2}{*}{ Alloy } & \multicolumn{9}{|c|}{ Composition, Wt. \% } & \multirow{2}{*}{$\begin{array}{l}\text { Test } \\
\text { Time, } \\
\text { days }\end{array}$} & \multirow{2}{*}{$\underset{{ }^{\circ} \mathrm{C}}{\text { Temp., }}$} & \multirow{2}{*}{$\begin{array}{l}\text { Average } \\
\text { Corrosion } \\
\text { Rate, } \\
\text { mils/day }\end{array}$} \\
\hline & $\mathrm{A} 1$ & $Z_{n 2}$ & $\mathrm{Mn}$ & $\mathrm{Ni}$ & Si & Th & $\mathrm{Z} x$ & $\mathrm{Be}$ & $\begin{array}{l}\text { Rare } \\
\text { Earth }\end{array}$ & & & \\
\hline $\begin{array}{c}\text { Pure } \mathrm{Mg} \\
\text { (Doma1) }\end{array}$ & & & & & & & & & & $\begin{array}{l}2.9 \\
5.0 \\
1.7\end{array}$ & $\begin{array}{l}120 \\
135 \\
150\end{array}$ & $\begin{array}{c}\text { Disinte- } \\
\text { grated } \\
\text { Disinte- } \\
\text { grated } \\
\text { Disinte- } \\
\text { grated }\end{array}$ \\
\hline$A z-31$ & $2.5-3.5$ & $0.7-1.3$ & 0.2 & & & & & & & $\begin{array}{l}2.9 \\
5.0 \\
2.7\end{array}$ & $\begin{array}{l}120 \\
135 \\
150\end{array}$ & $\begin{array}{l}0.2 \\
1.0 \\
3.2\end{array}$ \\
\hline PE & 3.2 & 1.0 & 0.1 & & & & & & & $\begin{array}{l}2.9 \\
5.0 \\
2.9\end{array}$ & $\begin{array}{l}120 \\
135 \\
150\end{array}$ & $\begin{array}{l}0.2 \\
0.9 \\
3.5\end{array}$ \\
\hline$A z-91$ & $8-9$ & $0.4-1.0$ & 0.13 & 0.01 & 0.3 & & & & & 1.7 & 150 & 3.1 \\
\hline $\mathrm{HZ}-32(\mathrm{ZTl})$ & & 2.5 & & & & $2.5-4.0$ & 0.7 & & & 2.7 & 150 & 1.2 \\
\hline$E K-41 A^{1}$ & & 0.3 & & & & & $0.4-1.0$ & & $3-5$ & 5.0 & 140 & $\begin{array}{r}\text { Disinte- } \\
\text { grated }\end{array}$ \\
\hline$A-3 \times A^{d}$ & $2.5-3.5$ & & & & & & & trace & & 5.0 & 150 & $\begin{array}{c}\text { Disinte- } \\
\text { grated }\end{array}$ \\
\hline
\end{tabular}

From data of N. Grant, Reactor Engineering Division, ANL.

\section{Alloy Development}

In an effort to improve the corrosion resistance of magnesium at $150^{\circ} \mathrm{C}$, about thirty-five special alloys were made and corrosion tested. The compositions and corrosion results are summarized in Table II. In general, these alloys may be grouped into the following classes: aluminum binaries, aluminum-copper ternaries, and aluminum-copper-tin or zinc quaternaries.

The results in Table II indicated that copper was the most effective addition for producing significant improvement in the corrosion resistance of magnesium-aluminum binaries. Tin or zinc produced additional improvement. Tin was preferred for nuclear reasons: it has a lower neutron absorption cross section.

The effects on corrosion resistance of varying these three elements are shown in Tables III, IV and V. These are excerpts of data from Table II and illustrate in more convenient form the basis for choosing the optimum alloy. No special significance should be attached to variations of a few tenths of a mil per day in corrosion rates since duplicate tests frequently showed this great a difference. 
TABLE II

Coxrosion of Developmental Magnesium Alloys in Initially Pure Water at $150^{\circ} \mathrm{C}$

\begin{tabular}{|c|c|c|c|c|c|c|c|c|c|c|c|c|}
\hline \multirow{2}{*}{ Alloy (1) } & \multicolumn{10}{|c|}{ Composition, Wt. $\%$} & \multirow{2}{*}{$\begin{array}{l}\text { Time } \\
\text { Test, } \\
\text { days }\end{array}$} & \multirow{2}{*}{$\begin{array}{c}\text { Corrosion Rate, } \\
\text { mils/day }\end{array}$} \\
\hline & Al & $\mathrm{Ce}$ & $\mathrm{Cu}$ & $\mathrm{Mn}$ & $\mathrm{Ni}$ & $\mathrm{Pb}$ & $S_{n}$ & $T \mathbf{i}$ & $\mathrm{Zn}$ & $\mathrm{Z} \mathbf{r}$ & & \\
\hline $\mathrm{Ml}^{(2)}$ & & & & & & & & & & 1 & 0.8 & $\begin{array}{l}\text { Completely } \\
\text { oxidized }\end{array}$ \\
\hline M2 & & 0.5 & & & & & & & & & 2.7 & $\begin{array}{l}\text { Completely } \\
\text { oxidized }\end{array}$ \\
\hline M3 & 5 & & & 0.1 & 0.5 & & & & & & $\begin{array}{l}0.9 \\
4.8\end{array}$ & $\begin{array}{l}2.0 \\
1.8\end{array}$ \\
\hline $\mathrm{M} 3 \mathrm{X}$ & 5 & & & 0.1 & 0.5 & & & & & & 0.9 & 2.2 \\
\hline M4 & 15 & & & & & & & & & & $\begin{array}{l}4.8 \\
0.9\end{array}$ & $\begin{array}{l}2.6 \\
3.0\end{array}$ \\
\hline & & & & & & & & & & & 4.8 & 2.5 \\
\hline M5 & 5 & & & & & & & & & & 0.9 & 3.7 \\
\hline M6 & 5 & 0.1 & & & & & & & & 0.5 & 0.9 & 7.1 \\
\hline M7 & 5 & 0.1 & 0.5 & & & & & & & 0.5 & $\begin{array}{l}0.9 \\
2.8\end{array}$ & $\begin{array}{l}1.9 \\
2.1\end{array}$ \\
\hline M8 & 5 & & & & & & & 0.2 & & & 0.9 & 8.2 \\
\hline $\mathrm{M} 9$ & 5 & & 0.5 & 0.1 & & & & & 1 & & 3.5 & 1.5 \\
\hline M10 & 5 & & & 0.1 & & & & & 1 & & 0.8 & 3.2 \\
\hline$M 11^{(2)}$ & 10 & & & & 0.5 & & & & & & 0.8 & 4.4 \\
\hline $\mathrm{Ml}^{(2)}$ & 10 & & 0.5 & & & & & & & & 0.8 & 1.3 \\
\hline$M 12$ & 10 & & 0.5 & & & & & & & & 2.7 & 1.6 \\
\hline M13 & 5 & & 0.5 & & & & & & & & 2.7 & 1.8 \\
\hline M14 & 5 & & 0.5 & & & & & & 1 & & 3.8 & 1.7 \\
\hline & & & & & & & & & & & 3.8 & 2.0 \\
\hline M15 & 5 & & 2 & 0.1 & & & & & 1 & & 2.8 & 1.6 \\
\hline M16 & 5 & & 0.1 & 0.1 & & & & & 1 & & 2.8 & 2.3 \\
\hline M17 & 5 & & & 0.1 & & & 1 & & & & 1.0 & 1.8 \\
\hline & & & & & & & & & & & 3.8 & 2.1 \\
\hline M18 & 5 & & 0.5 & 0.1 & & & 1 & & & & 1.0 & 1.6 \\
\hline & & & & & & & & & & & 3.8 & 1.6 \\
\hline M19 & 2.5 & & 0.5 & & & & 1 & & & & 1.0 & 1.6 \\
\hline & & & & & & & & & & & 4.7 & 2.0 \\
\hline M20 & 7.5 & & 0.5 & & & & 1 & & & & 1.0 & 1.7 \\
\hline & & & & & & & & & & & 4.7 & 1.7 \\
\hline M25 & 5 & & 0.25 & & 0.25 & & 1 & & & & 1.7 & 1.1 \\
\hline & & & & & & & & & & & 6.8 & 1.3 \\
\hline $\mathrm{M}_{26}{ }^{(3)}$ & 3 & & 0.6 & & & & 1 & & & & 2.9 & 1.6 \\
\hline M27 & 2.5 & & 0.5 & & & & & & & & 2.8 & 2.4 \\
\hline M28 & 2.5 & & 0.5 & & & & 0.5 & & & & 2.8 & 1.9 \\
\hline M29 & 2.5 & & 0.5 & & & & 1 & & & & 2.8 & 1.6 \\
\hline M30 & 2.5 & & 0.5 & & & & 2 & & & & 1.8 & 2.4 \\
\hline & & & & & & & & & & & & Cracked \\
\hline M31 & 2.5 & & 0.5 & & 0.5 & & 1 & & & & 1.9 & 1.4 \\
\hline & & & & & & & & & & & 3.7 & 2.0 \\
\hline & & & & & & & & & & & 4.8 & 1.8 \\
\hline M32 & 2.5 & & 0.5 & & 0.25 & & 1 & & & & 1.9 & 2.0 \\
\hline & & & & & & & & & & & 3.7 & 2.2 \\
\hline M33 & & & 0.5 & & & & 1 & & & & 2.7 & 2.2 \\
\hline M34 & & & 0.5 & & & & & & & & 2.7 & 3.3 \\
\hline $\mathrm{BP}^{(3)}$ & & & & & & & 2 & & & & 2.8 & 3.0 \\
\hline $\mathrm{BP}_{13}{ }^{(4)}$ & 5 & & & 0.1 & & & & & & & 2.0 & 6.8 \\
\hline
\end{tabular}

(1) Except as noted, alloys were produced at ANL and tested in the hot-rolled and annealed condition.

(2) Tested as cast and annealed.

(3) Commercially cast to ANL specifications. Hot pressed, rolled, and annealed before test.

(4) Commercially cast to ANL specifications. Tested as cast and annealed. 
TABLE III

Effect of Aluminum Content on Corrosion of Some Magnesium Alloys in Initially Pure Water at $150^{\circ} \mathrm{C}$

\begin{tabular}{|l|c|c|}
\hline Alloy and Composition & $\begin{array}{c}\text { Test Time, } \\
\text { days }\end{array}$ & $\begin{array}{c}\text { Corrosion Rate, } \\
\text { mils/day }\end{array}$ \\
\hline M33: 0.5 Cu-1 Sn & 2.7 & 2.2 \\
M19: 2.5 Al-0.5 Cu-1 Sn & 4.7 & 2.0 \\
M18: 5.0 Al-0.5 Cu-1 Sn-0.1 Mn & 3.8 & 1.6 \\
M20: 7.5 Al-0.5 Cu-1 Sn & 4.7 & 1.7 \\
\hline
\end{tabular}

\section{TABIE IV}

Effect of Copper Content on Corrosion of Some Magnesium Alloys in Initially Pure Water at $150^{\circ} \mathrm{C}$

\begin{tabular}{|l|c|c|}
\hline Alloy and Composition & $\begin{array}{c}\text { Test Time, } \\
\text { days }\end{array}$ & $\begin{array}{c}\text { Corrosion Rate, } \\
\text { mils/day }\end{array}$ \\
\hline Pure Magnesium & 1.7 & Disintegrated \\
M34: 0.5 Cu & 2.7 & 3.3 \\
M16: $5 \mathrm{Al}-0.1 \mathrm{Cu}-1 \mathrm{Zn}-0.1 \mathrm{Mn}$ & 2.8 & 2.3 \\
$\mathrm{M} 14: 5 \mathrm{Al}-0.5 \mathrm{Cu}-1 \mathrm{Zn}$ & 3.8 & 1.7 \\
$\mathrm{M} 15: 5 \mathrm{Al}-2 \mathrm{Cu}-1 \mathrm{Zn}-0.1 \mathrm{Mn}$ & 2.8 & 1.6 \\
\hline
\end{tabular}

TABLE V

Effect of Tin Content on Corrosion of Some Magnesium Alloys in Initially Pure Water at $150^{\circ} \mathrm{C}$

\begin{tabular}{|c|c|c|}
\hline Alloy and Composition & $\begin{array}{c}\text { Test Time, } \\
\text { days }\end{array}$ & $\begin{array}{c}\text { Corrosion Rate, } \\
\text { mils/day }\end{array}$ \\
\hline M27: 2.5 Al-0.5 Cu & 2.8 & 2.4 \\
M28: 2.5 Al-0.5 Cu-0.5 Sn & 2.8 & 1.9 \\
M29: 2.5 Al-0.5 Cu-1.0 Sn & 2.8 & 1.6 \\
M30: 2.5 Al-0.5 Cu-2.0 Sn & 1.8 & $2.4(1)$ \\
\hline
\end{tabular}

(1) Sample cracking 
Based on these results, the optimum composition for nuclear reactors appeared to be in the range

$$
\mathrm{Mg}-(2.5-5.0) \mathrm{w} / \mathrm{OA}-(0.5-1.0) \mathrm{w} / \mathrm{OCu}=(0.8-1.2) \mathrm{w} / \mathrm{O} \mathrm{Sn} .
$$

Three alloys $(M-25, M-31$, and $M-32)$ were prepared in which nickel replaced part of the copper. The results were not as reproducible as would be desirable, but there were indications that nickel slightly improved the corrosion resistance of these alloys.

Alloys of the following compositions, made to order by Brooks and Perkins, were also corrosion tested at $150^{\circ} \mathrm{C}$.

\section{Binaries}

$\begin{array}{lrll}\mathrm{Zn} & 7 \%, & 3.5 \%, & 1 \% \\ \mathrm{Sn} & 10 \%, & & 0.5 \% \\ \mathrm{~Pb} & 20 \%, & 5 \%, & 1 \%\end{array}$

\section{Quaternaries}

$$
\begin{aligned}
& 5 \% \mathrm{Al}+0.1 \% \mathrm{Mn}+0.05 \% \mathrm{Be} \\
& 5 \% \mathrm{Al}+0.1 \% \mathrm{Mn}+0.5 \% \mathrm{Cu}
\end{aligned}
$$

Except for the Al-Cu-Mn quaternary, these alloys failed completely after short exposures to $150^{\circ} \mathrm{C}$ water This quaternary alloy corroded at the same rate as similar alloys produced at Argonne.

Beryllium binary alloys could not be prepared by this source However, Magnox "C" (1\% Al; $0.05 \%$ Be) from Magnesium Elektron Ltd., Great Britain, failed after short exposure to water at $150^{\circ} \mathrm{C}$.

Some of these alloys were heat treated $\left(420^{\circ} \mathrm{C}-1\right.$ hour - water quenched) in a manner intended to produce a supersaturated aluminum solution in the belief that the aluminum might prove more beneficial if dis solved in the magnesium. There was no appreciable effect on corrosion resistance.

\section{Coatings and Inhibitors}

Various chemical and electrochemical pretreatments described in Table VI were applied to $\mathrm{AZ}-31$ coupons. In addition, coupons treated by the commercial HAE* process were obtained. Attempts were also made to produce surface alloys by vacuum deposition of aluminum and aluminum plus copper, followed by heat treating.

*The HAE process is an anodic treatment carried out in an alkaline bath containing $\mathrm{KOH}, \mathrm{Al}(\mathrm{OH})_{3}, \mathrm{Na}_{3} \mathrm{PO}_{4}, \mathrm{KF}$, and $\mathrm{K}_{2} \mathrm{MnO}_{4}$. 
TABLE VI

Experimental Coatings Applied to AZ-31 Magnesium Alloy

\begin{tabular}{|c|c|c|c|c|}
\hline $\begin{array}{l}\text { Reagents, } \\
\% \text { by weight }\end{array}$ & $\begin{array}{c}\text { Temperature, } \\
{ }^{\circ} \mathrm{C}\end{array}$ & $\begin{array}{l}\text { Time, } \\
\text { min }\end{array}$ & Electrical data & Notes \\
\hline $\begin{array}{l}40 \% \mathrm{KF} \\
6.7 \%\left(\mathrm{NH}_{4}\right)_{2} \mathrm{HPO}_{4} \\
\mathrm{Bal} . \mathrm{H}_{2} \mathrm{O}\end{array}$ & 25 & 3 & $5 \mathrm{a} / \mathrm{dm}^{2} ; 120 \mathrm{VDC}$ & \\
\hline $\begin{array}{l}65 \% \mathrm{KHF}_{2} \\
35 \% \mathrm{NaHF}_{2}\end{array}$ & 200 & $1-5$ & $\begin{array}{l}2 \mathrm{a} / \mathrm{dm}^{2} ; \\
35-40 \mathrm{VDC} \text { or } \mathrm{AC}\end{array}$ & Monel Cathode \\
\hline $\begin{array}{l}\text { a) } 20 \% \mathrm{NaOH} \\
\text { b) } 10 \% \mathrm{NaF}\end{array}$ & $\begin{array}{c}180 \\
\text { Boiling }\end{array}$ & $\begin{array}{l}15 \\
60\end{array}$ & & \\
\hline $3 \% \mathrm{NaF}$ & 20 & $1-5$ & $90-120 \mathrm{VDC}$ & \\
\hline $32 \% \mathrm{NH}_{4} \mathrm{~F}$ & 25 & $1-5$ & $\begin{array}{l}2 \mathrm{a} / \mathrm{dm}^{2} \\
50-140 \mathrm{VDC}\end{array}$ & \\
\hline $\begin{array}{l}30 \% \mathrm{NH}_{4} \mathrm{~F} \\
25 \% \mathrm{KF}\end{array}$ & 25 & 4 & $\begin{array}{l}2 \mathrm{a} / \mathrm{dm}^{2} \\
60-80 \mathrm{VDC}\end{array}$ & \\
\hline $\begin{array}{l}4 \% \mathrm{NaF} \\
\frac{1}{2} \% \mathrm{NaOH} \\
\frac{1}{2} \% \mathrm{KMnO}_{4}\end{array}$ & 100 & $1-5$ & $2 \mathrm{a} / \mathrm{dm}^{2} ; \mathrm{DC}$ & $\begin{array}{l}\text { AC superimposed } \\
\text { on the } D C\end{array}$ \\
\hline
\end{tabular}

No long-lasting (more than 24 hours) beneficial effect was found for any of these pretreatments when samples were exposed to $150^{\circ} \mathrm{C}$ water.

AZ-3I specimens were also used to evaluate the effect of commonly used corrosion inhibitors at $150^{\circ} \mathrm{C}$. Sodium salts of dichromate, borate, phosphate and fluoride were tested (100 ppm anion concentration). Only the fluoride was effective. In solutions containing initially 50 to $100 \mathrm{ppm}$ $\mathrm{F}^{-}$, better than a threefold reduction in average corrosion rate was noted for three-day exposures. Sodium, potassium, ammonium, lithium and lead fluorides were tested. All were effective inhibitors for this alloy. However, fluoride additions did not materially improve the corrosion resistance of pure magnesium. In this case, samples completely disintegrated in less than two days of exposure.

Analysis of the solution in the autoclave before and after testing showed that the fluoride ion was consumed at a rate of about $0.3 \mathrm{mg}$ $\mathrm{F}^{-} / \mathrm{cm}^{2}$ of $\mathrm{Mg} /$ day. (The rate of fluoride depletion by stainless steel was less than 1/100th as fast.) In order to test at constant fluoride conditions, a constantly refreshed autoclave was used. Figure 3 indicates the type of corrosion curves obtained. All of the experiments are summarized in Table VII. These tests were two weeks in duration and the rates refer to the straight-line portion of the curve. There were slight induction periods at the three higher concentrations. The appearance of typical specimens is shown in Figure 4. 


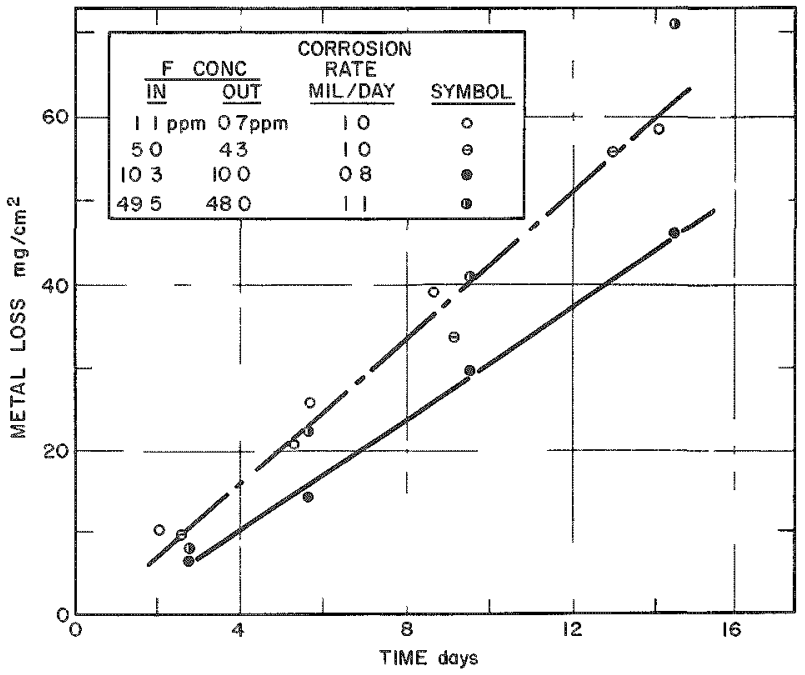
FIGURE 3 CORROSION OF AZ3I MAGNESIUM
ALLOY IN FLUORIDE SOLUTIONS

TABLEVII

Effect of Fluoride Concentiation on Colrosion of Magnesium Alloy AZ-31 at $150^{\circ} \mathrm{C}(1)$

\begin{tabular}{|c|c|c|c|c|c|}
\hline $\begin{array}{c}\text { Fluoride Conc, } \\
\text { ppm(2) }\end{array}$ & $\begin{array}{c}\text { Test } \text { Iıme, } \\
\text { days }\end{array}$ & $\begin{array}{c}\text { Coriosion Rate, } \\
\text { mils, day }\end{array}$ & $\begin{array}{c}\text { Fluoride Conc, } \\
\text { ppm (2) }\end{array}$ & $\begin{array}{c}\text { Test Time, } \\
\text { days }\end{array}$ & $\begin{array}{c}\text { Corrosion Rate, } \\
\text { mils/day }\end{array}$ \\
\hline $0^{(3)}$ & 5 & 33 & 10 & 14 & 08 \\
01 & 14 & 24 & 48 & 14 & 11 \\
07 & 14 & 10 & $8+4-5 \mathrm{ml} \mathrm{O}_{2} / 1$ & 7 & 17 \\
\hline
\end{tabular}

(1) Tested un refreshed system

(2) As NaF

(3) Closed autoclave test result included for comparison

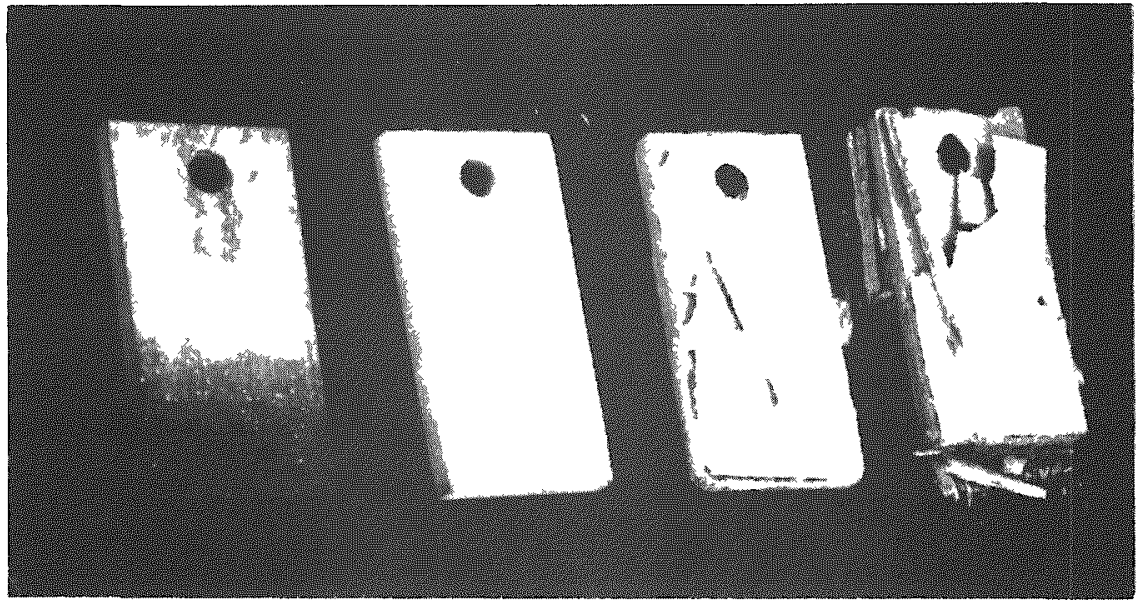

Figure 4

Appearance of AZ-31 Magnesium Alloy Corroded in 10 ppm Fluoride (NaF) Solution at $150^{\circ} \mathrm{C}$

22484 
It is evident that fluoride is somewhat effective at a concentration as low as $0.1 \mathrm{ppm}$. Between 1 and 50 ppm there is little effect of concentration on corrosion rate. An improvement in corrosion rate by a factor of between 3 and 4 was noted for these solutions as compared with water.

Tests were normally run with helium gas saturating the refreshing solution. In a single test, oxygen saturation of a solution containing $10 \mathrm{ppm}$ $\mathrm{F}^{-}$led to an increase in the corrosion rate by a factor of about 2 . In the $r$ efreshed system, as in the closed autoclaves, if no attempt at pH control was made, the $\mathrm{pH}$ of the system was about 10.5 .

It is possible that fluoride was effective is slowing the corrosion reaction primarily due to the low solubility of the magnesium fluoride formed. To test this hypothesis, preliminary tests were performed with solutions containing iodide, iodide plus fluoride, and chloride plus fluoride. As both $\mathrm{MgCl}_{2}$ and $\mathrm{MgI}_{2}$ are soluble, neither one should provide an insoluble film. In addition, it has been reported that chloride peptizes the corrosion product, making it less adherent. (5)

The results of these experiments are summarized in Table VIII. Iodide slowed the corrosion reaction, although it was not as effective as fluoride. Small amounts of iodide or chloride did not impair the effectiveness of fluoride.

\section{TABLE VIII}

Corrosion of Magnesium and Magnesium Alloys in Aqueous Halide Solutions at $150^{\circ} \mathrm{C}(1)$

\begin{tabular}{|c|c|c|c|}
\hline Material & $\stackrel{\text { Initial }}{\text { Conditions }}(2)$ & $\begin{array}{c}\text { Test Time, } \\
\text { days }\end{array}$ & $\begin{array}{c}\text { Corrosion Rate, } \\
\text { mils/day }\end{array}$ \\
\hline High-purity Mg & 120 ppm I & 2.6 & $\begin{array}{c}\text { Completely } \\
\text { oxidized }\end{array}$ \\
\hline$A Z-31$ & 0 & 5 & 3.3 \\
\hline AZ-31 Tube & 120 ppm I- & 2.6 & 4.0 \\
\hline AZ-31 Plate & $10 \mathrm{ppm} \mathrm{I}$ & 2.7 & 1.7 \\
\hline AZ-3I Plate & $\begin{array}{l}120 \mathrm{ppm} \mathrm{F}^{-} \\
+10 \mathrm{ppm} \mathrm{I^{- }}\end{array}$ & 2.7 & 0.6 \\
\hline AZ-31 Plate & $\begin{array}{l}120 \text { ppm } \mathrm{E}^{-} \\
+\quad 5 \mathrm{ppm} \mathrm{CI}\end{array}$ & 1.9 & 0.6 \\
\hline AZ-31 Plate & $\begin{array}{l}120 \text { ppm F' } \\
+10 \text { ppm } \mathrm{Cl}^{-}\end{array}$ & 1.9 & 0.6 \\
\hline AZ-31 Plate & $\begin{array}{l}120 \text { ppm } \mathrm{F}^{-\infty} \\
+10 \text { ppm } \mathrm{Cl}\end{array}$ & 2.7 & 0.5 \\
\hline
\end{tabular}

(1) Samples tested in closed autoclave (non-refreshed).
(2) Halide additions as sodium salts. 
Effect of $\mathrm{pH}$

The $\mathrm{pH}$ of solutions in which magnesium alloys corrode at $150^{\circ} \mathrm{C}$ reaches and remains about 10.5 (measured at room temperature with a glass electrode $\mathrm{pH}$ meter), or within the optimum range for lower temperatures. $(6)$

However, the alloy studies could be interpreted in terms of an important contribution of aluminum to the protective film formation. With this interpretation as a working hypothesis, it seemed reasonable to expect reduced corrosion rates at a lower $\mathrm{pH}$, favoring the formation of a resistant aluminum oxide incorporated in the magnesium oxide coating. Accordingly, the effect of $\mathrm{pH}$ with and without other additives was studied at $150^{\circ} \mathrm{C}$.

The effect of $\mathrm{pH}$ is summarized in Table IX.

TABLE IX

Effect of $\mathrm{pH}$ on Aqueous Corrosion of Magnesium Alloys at $150^{\circ} \mathrm{C}$

\begin{tabular}{|c|c|c|c|c|c|}
\hline \multirow{2}{*}{ Alloy } & \multicolumn{3}{|c|}{ Test Conditions } & \multirow{2}{*}{$\begin{array}{c}\text { Test Time, } \\
\text { days }\end{array}$} & \multirow{2}{*}{$\begin{array}{c}\text { Corrosion Rate, } \\
\text { mils/day }\end{array}$} \\
\hline & $\mathrm{pH}$ & $F^{-}, \operatorname{ppm}$ & $\mathrm{Cl}^{-}$, ppm & & \\
\hline \multirow[t]{13}{*}{$A Z-31$} & $4\left(\mathrm{H}_{2} \mathrm{SO}_{4}\right)$ & 0 & 0 & 6 & 2.0 \\
\hline & & 10 & 0 & 8 & 2.3 \\
\hline & $5-6\left(\mathrm{H}_{2} \mathrm{SO}_{4}\right)$ & 0 & 0 & 5 & 2.7 \\
\hline & $5-6$ & 10 & 0 & 7 & 3.3 \\
\hline & $6-7(\mathrm{HF})$ & 0.3 & 0 & 8 & 0.8 \\
\hline & $6-7$ & 10 & 0 & 4 & 0.4 \\
\hline & $6-7$ & 10 & 5 & 9 & 0.4 \\
\hline & $10.5^{(1)}$ & 0 & 0 & 5 & 3.3 \\
\hline & 10.5 & 10 & 0 & 14 & 0.8 \\
\hline & $12^{(1)}(\mathrm{KOH})$ & 0 & 0 & 2 & 2.1 \\
\hline & $12(1)$ & 120 & & 2 & 2.6 \\
\hline & $13(1)(\mathrm{KOH})$ & 0 & 0 & 2 & 2.3 \\
\hline & $13^{(1)}$ & 120 & 0 & 2 & 2.4 \\
\hline $\begin{array}{l}\text { Argonne Ml4 } \\
\text { (Commercially } \\
\text { Fabricated } \\
\text { Tubing) }\end{array}$ & $6-7(\mathrm{HF})$ & 10 & 0 & 5 & $0.1-0.3^{(2)}$ \\
\hline Argonne M26 & $6-7(\mathrm{HF})$ & 10 & 0 & 10 & $0.1-0.3^{(2)}$ \\
\hline $\begin{array}{l}\text { (Commercially } \\
\text { Fabricated } \\
\text { Tubing) }\end{array}$ & $6-7$ & 10 & 5 & 5 & 1.0 \\
\hline Pretreated & $6-7\left(\mathrm{H}_{2} \mathrm{SO}_{4}\right)$ & 0 & 0 & 4 & 1.0 \\
\hline$A Z-31(3)$ & $6-7(\mathrm{HF})$ & 0.3 & 0 & 4 & 0.1 \\
\hline
\end{tabular}

(1)

(2) Closed autoclaves; solution not refreshed during test.

(2) Corrosion rate given as range - poor reproducibility of results due to poor

(3) quality of tubing.

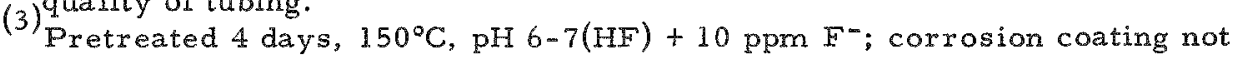
removed. 
Examination of the data indicated the following:

1) The optimum condition for minimum corrosion was pH of 6-7 with a fluoride content of about 10 ppm. Under these conditions commercial alloy. AZ-31 and the recommended Argonne-developed alloy were approximately equally resistant.

2) In the absence of fluoride, controlling the $\mathrm{pH}$ at values both lower and higher than the $\mathrm{pH} 10.5$ equilibrium value resulted in corrosion rates lower than the rate at the equilibrium value. At $\mathrm{pH}$ values of approximately 4 and 5, fluoride accelerated corrosion. At pH values above the equilibrium value, fluoride exerted little if any effect.

3) The presence of chloride under otherwise optimum conditions slightly increased the corrosion rate.

\section{DISCUSSION}

Since the experimental work was performed in support of specific reactor designs, tests were not operated under conditions to allow evalua tion of the effect of temperature on corrosion rate. Qualitatively, it has been shown here that the rate of corrosion in water increases rapidly with temperature, going from the order of $10 \mathrm{mdd}$ at $53^{\circ} \mathrm{C}$ to $1400 \mathrm{mdd}$ at $150^{\circ} \mathrm{C}$. Grant obtained a low corrosion rate ( $1 \mathrm{mdd}$ ) in a nonrefreshed test at $50^{\circ} \mathrm{C}$, but at $150^{\circ} \mathrm{C}$ his value agrees with ours. It is possible that the discrepancy near $50^{\circ} \mathrm{C}$ is a result of the reduction in corrosion rate due to the accumulation of corrosion product in his nonrefreshed test. As previously mentioned, Link noted this type of behavior in dynamic tests at $60^{\circ} \mathrm{C}$.

The corrosion behavior is correlated with the accumulation of cor rosion product rather than correlated with $\mathrm{pH}$, since: (a) conflicting estimates were obtained by the glass electrode $\mathrm{pH}$ meter and indicator paper: and (b) there was an increase in dynamic corrosion in the second set of tests at $90^{\circ} \mathrm{C}(\mathrm{pH}$ maintained by $\mathrm{KOH})$ when the solution was constantly replaced, even though the measured $\mathrm{pH}$ was higher

Very limited data suggest that oxygen increases corrosion. This was particularly pronounced in the stagnant test at $53^{\circ} \mathrm{C}$. Dynamic tests at $90^{\circ} \mathrm{C}$ showed little effect of oxygen saturation.

Pure magnesium demonstrated the poorest corrosion resistance of the alloys tested at temperatures above $100^{\circ} \mathrm{C}$. In this respect its behavior is similar to that of pure aluminum. The roles of the three beneficial alloying elements are not understood. It is thought that aluminum and tin (or zinc) serve to increase corrosion resistance as a result of the properties of the corrosion products. With these elements present, the cathodic alloying element is beneficial in pure water at elevated temperatures. It 
should be emphasized that the copper addition was desirable for the specific case of relatively pure water at elevated temperature. In making this alloying addition it is assumed that the resistance of the cathodic corrosion process is deliberately reduced to obtain a more than proportional increase in the resistance of the anodic corrosion process. This redistribution of resistances is possible only for certain corrosion media. The bulk of the data reported(1) for various solutions at lower temperatures indicate that copper would be undesirable in alloys designed for resistance to the more common corrosion-evaluating solutions.

Copper is apparently a more effective alloying agent than nickel. In view of the experience with aluminum, (4) this was somewhat surprising. However, it has been reported (2) that nickel is confined to the grain boundaries while copper in concentrations greater than $0.1 \%$ is distributed throughout the magnesium alloys. The improved distribution of the copper cathodic second phase would be expected to increase the corrosion resistance.

No effort was made to evaluate coatings or inhibitors at temperatures other than $150^{\circ} \mathrm{C}$. At this temperature no promising coating was found. Of the common inhibitors, only fluoride was useful. The reported low solubility of the fluoride corrosion product is apparently not the key to the mechanism of inhibition since other halides, producing soluble fluorides, were also shown to be somewhat effective in reducing the rate of corrosion. Optimum fluoride inhibition in systems without deliberate pH control reduced the corrosion rate of AZ-31 alloy by a factor of about three.

The control of $\mathrm{pH}$ in the range of $\mathrm{pH} 6-7$ with fluoride inhibition produced a striking reduction in corrosion rate. As previously mentioned, it is believed that the neutral $\mathrm{pH}$, favoring the production of a more corrosionresistant aluminum oxide, significantly improves the corrosion film properties at $150^{\circ} \mathrm{C}$ of magnesium alloys containing aluminum.

\section{CONCLUSIONS}

As has been discussed, the corrosion rates of magnesium alloys increased rapidly with increase in temperature. The results of these studies therefore did not indicate the possibility of using magnesium in hightemperature aqueous systems, except for highly specialized ones such as the high-flux research reactor in which high corrosion rates are tolerable because of an unusually short core life.

It has been demonstrated that, by appropriate methods, it is possible to reduce by a factor of about 30 the corrosion rate of selected magnesium alloys in static aqueous environments at $150^{\circ} \mathrm{C}$. Some aspects of these findings are in apparent contradiction to previous ideas. If inhibiting agents and improved alloys are correspondingly effective at lower temperatures 
and with rapid flow, the performance of low-temperature research reactors could be materially improved by the substitution of magnesium for aluminum. Certain nonnuclear uses might also prove feasible.

\section{ACKNOW LEDGEMENT}

We gratefully acknowledge the many helpful suggestions of Dr. J. E. Draley and Dr. R. D. Misch of this division, and the work of Mr. E. O'Keefe of General Electric (on loan to Argonne) on coatings.

\section{REFERENCES}

1. Uhlig, $H_{0} H_{0}$, Corrosion Handbook, J. Wiley and Sons, New York (1948), pp. 218-252.

2. Sock, Henri S. and Byron P. Roe, Literature Survey of the Corrosion of Magnesium and Magnesium Alloys, WADC-TR-56-478 (Sept. 1957).

3. Ruther, W. E. and W. B. Seefeldt, Aqueous Corrosion of Uranium and Uranium-6 w/o Zirconium Alloy, ANL-5672 (Jan. 1957).

4. Draley, J. E. and W. E. Ruther, Aqueous Corrosion of Aluminum, Part 2, Corrosion, $12480 t-490 t(1956)$.

5. Gatley, O. and E. C. R. Spooner, The Electrode Potential Behavior of Corroding Metals in Aqueous Solutions, Oxford University Press, London (1939).

6. Heal, T. J。Nuclear Engr. 3, 52-63 (February 1958). 